Volume 3

Issue 2 Organizations \& Institutions in the

Peace Process

Article 1

June 2017

\title{
Social Cohesion Through Cooperative Contact: A Theoretical Perspective
}

\author{
Ezechiel Sentama \\ University of Rwanda, esentama@gmail.com
}

Follow this and additional works at: https://digitalcommons.usf.edu/jacaps

Part of the Peace and Conflict Studies Commons, Regional Sociology Commons, and the Sociology of Culture Commons

\section{Recommended Citation}

Sentama, Ezechiel (2017) "Social Cohesion Through Cooperative Contact: A Theoretical Perspective," Journal of African Conflicts and Peace Studies: Vol. 3: Iss. 2, 1-15.

DOI: https://doi.org/10.5038/2325-484X.3.2.1091

Available at: https://digitalcommons.usf.edu/jacaps/vol3/iss2/1

This Article is brought to you for free and open access by the Open Access Journals at Digital Commons @ University of South Florida. It has been accepted for inclusion in Journal of African Conflicts and Peace Studies by an authorized editor of Digital Commons @ University of South Florida. For more information, please contact digitalcommons@usf.edu. 


\section{Introduction}

How to build social cohesion in a country that has been torn apart by a long history of division, discrimination, persecution, and violence, constitutes one of the difficult challenges. The existing literature, debates, and theorization, in this regard, have much focused on approaches and perspectives, such as Truth and Reconciliation Commissions, Problem-solving Workshops, and other mediation-based perspectives, which are public and involve the presence of a third party. This paper aims to contribute to existing knowledge by suggesting that approaches that are natural, private, and which do not involve a third-party intervention, constitute an effective alternative. With the use of contact hypothesis, this paper also aims to contribute to how or when contact will be most effective in building social relations or lessening prejudice between post conflict/violence divides.

The paper focuses on the experience of Rwanda - a country that is still recovering from a long history of identity-based division that culminated in one of the most brutal genocides in the history of humankind the genocide against Tutsi, between April and July 1994. It is estimated that more than one million people were killed, along with the profound devastation of the country's social, political and economic fabric. ${ }^{1}$ In addition to the extermination of Tutsi, several other Rwandans and some foreigners were also massacred for various reasons: some, for being politicians opposed to the genocidal regime and ideology; and others, for having refused to participate in killings or for having hidden the Tutsi. ${ }^{2}$

\footnotetext{
${ }^{1}$ See also in Sentama Ezechiel (2009). Peacebuilding in post-genocide Rwanda: The Role of Cooperatives in the Restoration of Interpersonal Relationships, Ph.D. Thesis, p.1.

2 The latest estimation counts 1,191,000 victims (see the Ministry of Youth, Culture and Sports \& Ibuka Association, 2004).
} 
The genocide in question came to halt with the victorious war by the Rwandese Patriotic Front (RPF) ${ }^{3}$, through its armed wing - the Rwandese Patriotic Army (RPA). After the genocide, the entire infrastructure of the country, ranging from schools, hospitals, and government departments, were totally destroyed or severely looted. The country was thus left with the traumatized survivors, countless orphans and widows, thousands of handicapped people, thousands of perpetrators, and generally a very traumatized and vulnerable population. In particular, a deep division between genocide survivors ${ }^{4}$ and genocide perpetrators ${ }^{5}$, as well as their respective family members, was evident. The post genocide new Government, constituted on July $19^{\text {th }}$, 1994 by a coalition of political parties headed by the RPF was thus faced with a huge challenge to (re)build social cohesion and unity in a country where by citizens were in total trauma and distress (NURC, 2009; Longari, 2010:49). The government claimed that social cohesion is a dynamic innate in Rwandan society that can be rediscovered in the current context by instituting practices, such as those embodied in traditional community or collaborative programs (NURC, 2009; Clark, 2010:310).

Implicit in the government perspective was a belief that certain modes of citizens' participation are necessary if groups in conflict wish to relearn how to coexist (Clark, 2010:310). Some scholars also stress that, in order to build new relationships, a social space where people can recount their experiences and share perceptions and feelings with one another through an encounter, is necessary (Lederach, 1997:26, 29; Borer 2006:33, Crocker et al., 2007). It is in this perspective that cooperative organizations, as such a social space, are assumed to be recruiting vehicles through which post-genocide social cohesion could be driven. According to the International Cooperative Alliance (ICA) ${ }^{6}$, a cooperative is "An autonomous association of persons united voluntarily to meet their common economic, social and cultural needs and aspirations through a jointly-owned and democratically-controlled enterprise" (ICA, 1995). Whether, and how, cooperative contact contributes to social cohesion, after violent conflicts, is the aspect at the core of this paper.

\footnotetext{
${ }^{3}$ RPF (Rwandese Patriotic Front) is the political party that was formed by the Rwandan refugees of since 1959 out of the Alliance for National Unity (RANU) with the intent to fight for democratic change in Rwanda.

${ }^{4}$ By 'genocide survivor', this paper refers to any individual, irrespective of his/her 'ethnic' or 'group' background, who, in a way or another, was either injured, hunted, or targeted by genocidal acts. In this regard, the study chose to employ the concept of 'survivor' instead of the term 'victim', not only because the term 'survivor' is familiar and widely used in much of the literature on postgenocide situation, and above all in Rwanda, but also since the term 'victim' could be misleading, given that it can be used for both the offended against and the offender (Sentama, 2009:6-7).

${ }^{5}$ By 'genocide perpetrator', this paper refers to any individual, irrespective of his/her 'ethnic' or 'group' background who, in a way or another, got involved in genocidal acts. In this regard, this study does not consider 'bystanders' - understood as people who did not, or were less likely to, offer help in fighting or challenging genocidal acts - as belonging to the category of genocide perpetrators. What could perhaps be argued for is that (some) 'bystanders' could be/have been family members of former genocide perpetrators (Sentama, 2009:7).

${ }^{6}$ The International Cooperative Alliance (ICA), created in 1895, is the highest international organization accepted as the final authority for defining cooperatives and their underlying principles.
} 
Specifically, the paper explores the following questions:

1. What is the nature of the relational effects resulting from contact, in the cooperative organization, between post-genocide sides?

2. What have been the forms of the relational effects resulting from contact, in the cooperative organization, between post-genocide sides?

3. To what degree or extent did cooperative contact, in the cooperative organization between post-genocide sides, produce the relational effects?

The forms, referred to in question two, are about the actors involved in the cooperative contact; that is, whether the relational impact of cooperative contact takes place between individuals, individual and group, or between groups. The degree of cooperative contact referred to, in question two, is about the extent of the relational effects of cooperative contact; that is, whether the contact outcomes constitute a retrospective or prospective outcome.

\section{Positioning the concept of 'Social cohesion'}

The notion of 'social cohesion' has remained vague and poorly defined. As a policy goal, the concept gained great prominence in the 1990s, with an eye on building multicultural societies where all members feel a sense of belonging and have equal access to opportunities and resources. It has since also risen to prominence in international development circles, where it is considered as key to the achievement of growth and the reduction of economic inequality (Easterly, Ritzen, and Woolcock, 2000 in NURC, 2008:26). In the most basic and intuitive sense, social cohesion refers to "something that glues us together" or "the glue that bonds society together" (Lederach, 1997; Ho-Won, 2005).

The most generic recent definition of social cohesion sees it as "a state of affairs concerning both the vertical and the horizontal interactions among members of society as characterized by a set of attitudes and norms that includes trust, a sense of belonging and the willingness to participate and help, as well as their behavioral manifestations." In this definition, the "vertical" interactions refer to the relationship between the state and individuals in society, while "horizontal" interactions are between individual members of society (NURC, 2008:26). This paper is restricted to the horizontal dimension of social cohesion and, by taking an interpersonal/intergroup relational perspective, defines social cohesion as the belief and feeling held by citizens of a given nation-state that they share a moral community, which enables them to trust each other and live interdependently (International Institute of Social Studies, 2013; Larsen, 2013).

\section{Theoretical perspective: the contact hypothesis}

The 'contact hypothesis' stands as the theoretical framework for making social cohesion effective, with regard notably to the attempt to create the conditions of optimal contact toward the establishment of positive interpersonal or intergroup relations. Theorizing about the place of contact toward social cohesion can be traced back to the nineteenth century, whereby theorists began to speculate about the effects of contact between conflicting parties long before there was a research base to guide them. Some writers (notably during nineteenth century thinking, dominated 
by Social Darwinism) were quite pessimistic, as they assumed that interpersonal or intergroup contact would inevitably lead to conflict. Others were more optimistic, with the assumption that such contact would rather foster mutual understanding. It was during early studies, especially following the Second World War, that research stressed that intergroup contact would maximally reduce prejudice, provided that a number of conditions were fulfilled (Sentama, 2009:34). However, the most frequently cited statement of the contact hypothesis, which distinguishes different types of contact (requirements for change) that may reduce prejudice was first provided by Gordon Allport (1954). For Allport,

\begin{abstract}
"prejudice (unless deeply rooted in the character structure of the individual) may be reduced by equal status contact between majority and minority groups in the pursuit of common goals. The effect is greatly enhanced if this contact is sanctioned by institutional supports (i.e., by law, custom or local atmosphere), and provided it is of a sort that leads to the perception of common interests and common humanity between members of the two groups." (Allport, 1954:281)
\end{abstract}

The above statement of Allport's conclusion emphasizes that prejudice is lessened when there is: (1) equal status between the groups within the contact situation; (2) in the pursuit of common goals, interests and humanity, which stresses the importance of; (3) cooperative interdependence (instead of competition) and thus a superordinate role relation involved instead of a subordinate one (Allport, 1954:262, 276); and (4) provided that the contact situation is sanctioned by institutional supports (i.e., by law, custom or local atmosphere) (Allport, 1954:281). For the purpose of this paper, the 'cooperative interdependence' condition, suggested by contact theory, is of particular importance. The simple and general argument, in this regard, is that attainment of a common goal, or common goals, by participants in the contact situation must be an interdependent effort without intergroup competition (Allport, 1954; Hewstone, 2003:352; Pettigrew and Tropp, 2006). What is clear is that contact involves different attitudes and behaviors depending upon whether the individuals in contact are either cooperating with each other or fighting each other (Sentama, 2009:37). Contact theory does not claim (although of course it also does not deny) that conflict or cooperation between two ethnic groups may have effects on the ethnic attitudes of their members. The point is that the ethnic attitudes of individuals, who are unavoidably members of particular ethnic groups, are undoubtedly influenced by the relations of cooperation or competition that exist between their groups. If two groups share a common or 'superordinate' goal that requires a joint effort for its attainment by both groups, then the relations between their members are likely to be better, and their attitudes towards each other more positive, on average, than if the two groups were competing for a goal that only one can have (Forbes, 1997:122; Sentama, 2009:38).

Researches, since Allport's original formulation, have extended Allport's ideas about when contact will be most effective. It is in this perspective that this paper believes to bring its contribution. The contact hypothesis thus constitutes a framework within which the relational effects of cooperative contact, between the sides, are explored and discussed. 


\section{Methodology}

This paper is a result of a qualitative study which, by means of individual and focus group interviews, explored the relational effects of two cases of cooperative organizations, operating in Huye district of the southern province of Rwanda, which were created soon after the 1994 genocide, before even the government embarked officially on the road to reconciliation notably by creating, in March 1999, a public institution (the National Unity and Reconciliation Commission) with a mandate to lead and coordinate all efforts toward unity and reconciliation in Rwanda. ${ }^{7}$

Both cases of cooperative belong to the major sectors of livelihood in Rwanda, notably agriculture and handicraft, respectively, and members of each cooperative are constituted of post-genocide sides-genocide survivors and genocide perpetrators, as well as their respective family members. The first cooperative, Abahuzamugambi coffee, was created in January 1999, with members totaling 2,326. This is a coffee cooperative located in the Simbi sector of Huye district, in the southern province of Rwanda. The cooperative's main focus is to buy fresh coffee of cooperative members, and process the coffee for internal and external commercialization. Participants in individual and focused group interviews totaled 151. The second cooperative-Peace basket-was created in 1997, with members totaling 38 , at the time of investigations. It is a handicraft cooperative (weaving the baskets for commercialization) located in Buhimba cell of Rusatira sector, in Huye district of the southern province of Rwanda. All members participate in individual and group interviews.

\section{Findings and discussion}

As indicated previously the exploration of the relational effects of cooperative contact, between the divides, focuses on the nature, the forms and degrees of such effects. But before getting to that, it is of paramount importance to indicate how the relationships between post-genocide divides were, prior to their membership of the same cooperative organization, and the reasons that prompted them to form or join that same cooperative.

\section{Conflicting parties relations prior to, and reasons for, their membership in the same cooperative organization}

As findings indicate, the relationships between post-genocide sides, prior to their membership of each of the cooperatives visited, were negative and included the absence of communication, fear, suspicion and mistrust, as well as anger and hatred, for each side. This is illustrated in the following testimonies:

After the genocide! Hehehe! We were animals! We were like hyenas! I am telling you! I could even eat you [somebody]! Eh! I was left alone, you understand! When the genocide ended! We, survivors! We hated anybody who is a Hutu. But we also feared them as we thought they will kill us again. Fear was everywhere. ${ }^{8}$

\footnotetext{
${ }^{7}$ Empirical data were actually collected in 2008 as part of my $\mathrm{PhD}$ thesis.

${ }^{8}$ Interview with a 59 years old genocide survivors. This statement is also quoted in Sentama 2009:93
} 
Yes, there was division between us. Our people have been killed badly. After the genocide, I couldn't not even wish to see them again! Of course I only wanted to know how my family members were killed; who killed them, and where they have been thrown! But I am telling you, when they saw me they all fled as they were afraid of me! But I was also afraid!

Despite the possibility that other mechanisms could have impacted on cooperative members' relationships (like the Church), the wounds consequent to the 1994 genocide were still fresh, by the time the two cooperatives visited were created, coupled with the fact that the Church had already lost its credibility given its involvement, precisely its leaders, in genocidal acts, which explain the fact that post-genocide relations and attitudes between the sides were still negative. The question is now whether their membership of the same cooperative (Abahuzamugambi coffee and Peace basket, in this case) was motivated by a desire to restore these negative relationships. Findings in this regard are summed up in the following illustrative testimonies:

Me I joined the basket cooperative because I wanted to fight against poverty. I was extremely poor. My husband was in jail and I was left with no children! It was very bad! $!^{10}$

Me too, what I can say which is the same as what my fellows said. I believed that by joining this cooperative I will be able to fight against my poverty. You know that during genocide all our properties were destroyed and others looted. Also, by joining this cooperative, I believed that I could ease the fatigue I had while working alone in my coffee plantation; that is, while maintaining, harvesting, and sorting coffee alone. So I was obliged to work with everybody. ${ }^{11}$

As emphasized in the above accounts, the reason that prompted post-genocide sides to form or join the same cooperative was in no way aimed at building peaceful relations between them. Instead, the purpose was to address a problem-poverty, which was common to both sides of the conflict and which could not have been overcome by each side on his/her own. The only alternative was for individuals from both sides of the conflict to join efforts.

In fact, in the aftermath of the 1994 genocide, and the civil war, individuals from both sides of the conflict, who were accustomed to working together or supporting each other before the genocide, faced extreme poverty in a more or less similar way. Addressing the problem of deep poverty thus seemed very difficult, or even impossible for many, while working individually - all the more so since many people were left orphaned or widowed, and many households left headed by young people. Conflicting parties thus found themselves obliged to combine effort in order to increase production and thus income, in comparison with the market or privatecapitalist sector.

\footnotetext{
${ }^{9}$ Interview with a 64-year-old widow-genocide survivor and president of Peace basket cooperative.

${ }^{10}$ Interview with a 49 -year-old female-family member of former genocide perpetrators.

${ }^{11}$ Interview with a 48 years old widow, genocide survivor. This statement is also quoted in Sentama 2009:97
} 
Given that both sides of the conflict lived side by side, they found themselves in need of each other and thus met in order to fight against the common problem of poverty. Fighting against poverty through the cooperative required that people thus adopt a new spirit-working together or cooperative interdependence (Sentama, 2009:164). In connection with the contact hypothesis, poverty was, in this case, a superordinate goal (an urgent goal that could only be achieved by cooperation between conflicting parties). There is thus need to know what happened to the sides' relations after their membership of the same cooperative organization.

\section{Conflicting parties relations after their membership of the same cooperative organization}

As findings, indeed summarized in the accounts below, indicate even though postgenocide divides did not form or join the same cooperative in order to restore their relationships, their attitudes and relations changed positively with as a result of their membership of each of the two cooperatives visited. Illustrative accounts in this regard appear self-explanatory:

Me! I was in prison, I sinned [committed genocide] and I acknowledged that. I repented because my heart was not stable given what I had done. People forgave me, and I was thus released from prison. When I came into this cooperative, I found all the people there, genocide survivors, those who are not genocide survivors, all are in the cooperative! I was surprised. After some days, I realized that they are rather united when we converse. The simple fact that we work together for the same goal is very important. No intrigues; we work together without any problem. When we are in that coffee plantation, people are all mixed and we work in these coffee plants together. There is no ruse here; we get money and we are happy together; we even celebrate that! Yes, in our convivial parties. ${ }^{12}$

Trust! That is the first thing we have in this cooperative. Eh! We share everything, we eat together; we no longer think of poison like before. If we borrow money from each other and support each other in whatever circumstance, what do you want me to add? Of course trust does not come immediately; you must cultivate it; and this is what this cooperative helps us to do; conversations! Oh! I am happy with that. ${ }^{13}$

That is right, trust? Yes, trust is there in this cooperative. It developed little by little as we were conversing and supporting each other. But before [membership]! I am telling you; we couldn't even look at each other! This cooperative developed trust among us; and indeed, as I told you, this goes back to that contact which favors conversations and conviviality. For example, when you go in the cabaret and buy a bottle of beer, you give to him, because you know each other in the cooperative, and he became your friend; you share with him because there is no longer suspicion of poisons; there is trust because we are in the same cooperative and we always have good conversations. But before our membership, suspicion was there. ${ }^{14}$

\footnotetext{
${ }^{12}$ Interview with a 47-year-old male-former genocide perpetrator, who was imprisoned and released after confessing. This statement is also quoted in Sentama 2009:101.

${ }^{13}$ Interview with a 50 year-old male family member of former genocide perpetrators. This statement is also quoted in Sentama 2009:107.

${ }^{14}$ Interwiew with a 53-year-old male-genocide survivor. This statement is also quoted in Sentama
} 
Of course there is still a long way to go; but for us, because of this cooperative, this is a reality. Yes, it is true. Because of this cooperative, people changed; they are marrying each other, for example, my daughter, recently, married a Hutu boy! It is because me and the boy's parents became friends when we met in this cooperative. Actually we hated all Hutu because genocide was perpetrated in the name of Hutu and that many Hutu killed; but the reality is that there are Hutu who did not kill; some have even been killed while trying to hide ours! Of course, it is not easy to admit this for most of people who suffered a lot, but for us who have been educated, we find that normal. The past should be surpassed. ${ }^{15}$

The above accounts of individuals from both sides of the conflict indicate clearly how the relationships, between the divides, in the cooperative organization became positive as a result of their membership of the same cooperative organization. Even though the sides' contact in the same cooperative was not motivated by their desire to restore their broken relationships, their membership to the cooperative, made them engage in new positive spirit and ways (cooperation) of communication and engagement, which impacted positively on their relationships. It was thus this new spirit (complying with cooperative values and principles towards a common end), to which each cooperative member had to submit, that mainly lies behind the positive impact of cooperatives studied on their members-conflicting parties' relationships.

By adopting the cooperative spirit towards a common end, conflicting parties were thus called to put aside what divided them and focus on what united them, hence peaceful relations. As found, the setting aside of divisions does not imply their burial or keeping them from discussion. It rather became an opportunity to discuss and transform them constructively. Conflicting parties' successful achievement of a common end thus necessitated that they positively redefined and transformed their previous negative relationships. ${ }^{16}$ This was made possible as they engaged in cooperative education (one of the key cooperative principles) in a way that made them submit to key cooperative values of equality, equity, solidarity, honesty, openness, and social responsibility that bind all behaviors and actions of cooperative members and to whom they are constantly taught. As Deutsch puts it, cooperative relationships display a number of positive characteristics, including more effective communication, open and friendly attitudes, and a sense of mutuality, while competitive processes tend to yield the inverse, negative effects (Deutsch, 2000:27).

Even though, as put in the theoretical framework, contact theory does not claim (although of course it also does not deny) that conflict or cooperation between two ethnic groups may have effects on the ethnic attitudes of their members, the experience of the relational effect of cooperative contact in post-genocide Rwanda confidently claims that. This paper indeed agrees with the principle in the social sciences that states that whenever the cooperation of two people is enlisted toward the completion of some task that is of equivalent importance to both (and which

\footnotetext{
2009:107.

${ }^{15}$ Interview with a 52-year-old widow-genocide survivor. This statement is also quoted in Sentama 2009:105.

16 See also in Sentama, 2009:164).
} 
cannot be successfully completed except through the close cooperative enterprise of the two people), those people will come to like each other, they will become friends, and their values, attitudes, goals, etc., will tend to become increasingly similar. This, as contact theory posits, is known as the principle of the superordinate goal, describing cooperation to solve mutual problems (Gilmartin, 1987:286; Love, 1995:56). A superordinate goal is "an urgent goal that could only be achieved by cooperation between the conflicting groups" (Ryan, 1995:137). In this regard, cooperation refers to a pro-social behavior performed for the common benefit of all. It involves sharing both the labor and the fruits of the labor (Worchel et al., 1989:213). Amir also argues that contact may intensify negative attitudes in the absence of superordinate goals, or when one side is disadvantaged by the contact (Amir, 1998:174-8). The point here is that cooperative activities tend to improve intergroup relations, while competitive activities may have a negative effect (Amir, 1998).

Likewise, even if contact theory neither claims nor denies that the relations between two individuals in contact are likely to be greatly affected by what these individuals actually do to each other, Rwanda's experience of cooperative contact claims this. The point is that the more conflicting parties help each other to attain important goals, so that both are better off as a result of their interaction, positive attitudes are more likely to develop between them than if they spend their time insulting, frustrating, or torturing each other (Forbes, 1997:123). This refers to the general belief that when opponents can be brought together in some cooperative endeavor, they tend to break down their negative stereotypes, begin to depend on each other, and start building normal, positive relationships which can later be extended to issues in conflict. ${ }^{17}$

As found in this study, the application of cooperative values implies that each member of the cooperatives studied strives for, and is responsible for, the wellbeing of his/her fellow members - a cooperative exercise that excludes competition among group members while favoring interdependence and mutual understanding among members. Conflicting parties' decision to work together to satisfy a common need - an activity involving participation and interdependence-was a result of a positive expectation that each side had in relation to the others. Each side expected that the other side would contribute to his or her well-being, and thus accepted working together interdependently, given that both sides were expected to share the success or the failure of their cooperative. It follows that they all strove towards the success of the cooperative, which implies a common understanding and eventually trust, with ultimately positive consequences on their relationships. The relatively simple act of trusting that each side of the conflict would contribute to the well-being of the other was thus found to be an important aspect characterizing

\footnotetext{
${ }^{17}$ See also in Sentama, 2009.
} 
conflicting parties' improved and restored relationships. This would arguably not have been possible in the case of competition. ${ }^{18}$

Both cases of cooperatives studied provided a safe environment, where conflicting parties managed to positively communicate/discuss and share their past experiences, perceptions, and feelings, while understanding each other, during a common project of striving towards a common end and a positive future in their relations. ${ }^{19}$ This supports the common contention in the literature on intergroup contact, as discussed previously, contending that if conflicting parties help each other to attain important goals, so that both are better off as a result of their interaction, positive attitudes are more likely to develop between them than if they spend their time insulting or frustrating each other. The cooperative work thus enables the interdependence of cooperative members towards a common goal, which consequently became an opportunity for the restoration and improvement of their relationships - given that members were conflicting parties. In other words, when opponents manage to be brought together in some cooperative endeavor, they tend to break down their negative attitudes and behaviors, they naturally begin to depend on each other, and they therefore start building normal, positive relationships, a process that becomes extended to previous negative aspects of their relationships.

With regard to the form and degree of the relational effects of cooperative contact, empirical findings indicate that concerning the forms, the relational effects of contact between the sides consider two forms of relationships (between individuals, between individuals and out-groups). The group-to-group relations do not thus manifest in the cooperative organization given that membership to the cooperative is done on an individual basis. It follows that the positive relational effects of individual contact in the cooperative take place at individual level first and are then extended to the outer group.

Concerning the extent or degree of the relational effects of cooperative contact, the focus is on both the retrospective and the perspective dimensions. Not only conflicting parties discuss about the past conflict, notably what divided them, but also, and most importantly, they engage in building the positive future in their new relationships. Although the official discourse in Rwanda seems to consider social cohesion by putting much more emphasis on the sole retrospective sense in order to restore national unity, claimed to have existed in pre-colonial Rwanda, the experience of cooperative explored suggest that it is much more sustainable to focus on both the retrospective and the perspective dimensions as cooperative contact does. Cooperative members, not only discuss the root causes and the effects of the genocide, but also engage in new relationships that also bear a preventive dimension. In this regard, cooperative education was found to be aimed at engaging the minds of cooperative members, not only to fully comprehend the complexity and richness of cooperative thought and action, but above all to appreciate the

\footnotetext{
${ }^{18}$ See also in Sentama, 2009.
}

${ }^{19}$ See also in Sentama, 2009. 
requirement of members' unity and interdependence toward an end they share in common, which is the overarching goal behind the creation of their cooperative. ${ }^{20}$

Ideologically, as Carlsson (1992:44) indeed holds, cooperatives are human-centred, with cooperation seen as a process of education, and of development of people. As found in this study, education for cooperatives' economic success focused on members' awareness of cooperative spirit (values and principles) and members' communication and interdependence towards a common goal. In this regard, as found, the education provided contributed to social cohesion rather than being a conflict-exacerbating factor. It is reminded that for both cases of cooperatives studied, education was transmitted in three ways: (a) during cooperative work (advice, councils and warnings while working together), (b) during training sessions (by members themselves), and (c) during convivial parties (ritual ceremonies celebrating the cooperative achievements). In this regard, cooperative education and training was a persuasive force, which drew conflicting parties closer together, and governed and controlled their attitudes and behaviors positively. The outcome is that when cooperative members (conflicting parties) were constantly trained on attitude and behavioral change, and were requested to submit to, and internalize, the new philosophy of cooperation (values and principles), towards a common end, they began to gradually give up their negative or hostile-dehumanizing attitudes and behaviors towards each other, as they adopted and internalized positive-humanizing ones. $^{21}$

\section{Conclusion}

This paper discussed the nature, the form and the degree of the social cohesion effects resulting from contact, in the cooperative organization, between postgenocide sides in Rwanda. The paper explored two cases of cooperativesAbahuzamugambi and Peace basket and suggests that, by virtue of its guiding peaceful values and principles, the cooperative contact stands as an effective private and natural method for social cohesion after violence. Even though post-genocide sides initially came into contact, in the cooperatives studied, in order to cooperatively satisfy another need (fighting against poverty), rather than to restore or improve their relationships, it was found that in the end the cooperative spirit impacted positively on their relationships, as they engaged in a cooperative education and work that naturally nurtured mutual positive communication and understanding tor educe poverty, together. Since both sides of the conflict faced the common problem (poverty), it was found that their joint effort in striving to fight against it successfully became an opportunity for them to meet on an equal basis, interact democratically, and work together constructively, in a way that enabled them to not only overcome mutual negative attitudes and feelings, but also to engage in new positive ones.

\footnotetext{
${ }^{20}$ See also in Sentama, 2009.

${ }^{21}$ See also in Sentama, 2009.
} 
With regard to the form and degree of the relational effects of cooperative contact, empirical findings indicate that the relational effects of contact between the sides consider two forms of relationships (between individuals/individual-to-individual form and between individuals and out-groups/individual-to-group form). With regard to the extent or degree of the relational effects of cooperative contact, the focus is on both on the retrospective and the perspective dimensions. Cooperative members not only discuss the root causes and the effects of the genocide, but also they engage in new future relationships that also bear a preventive dimension in a way that is private, intimate and natural.

This paper thus claims to have contributed to the theoretical debate when it comes to how to successfully achieve social cohesion after violent conflicts. Unlike other social-cohesion approaches and perspectives (Truth Commissions, Problem-Solving Workshops, and similar approaches), which are public and involve a third party, cooperative contact involves a people-to-people/group's natural approach without public involvement or a mediator, which thus suggests that cooperative contact constitutes an alternative approach to social cohesion after violent conflicts.

\section{References}

Allport Gordon Willard (1954). The Nature of Prejudice. Cambridge, MA: Addison-Wesley Publishing Company, Inc.

Birchall Johnston (2003). Rediscovering the cooperative advantage: Poverty reduction through self-help. Geneva: International Labour Organization.

Boulding Elise (1994). Introduction to Rethinking Peacebuilding. Available at: http://www.gmu.edu/academic/pcs/boulding.htm.

Brewer Marilynn B. (2003). Intergroup Relations. $2^{\text {nd }}$ Ed., Buckingam and Philaderphia: Open University Press.

Burgess Heidi (2003). "Stereotypes / Characterization Frames". Beyond Intractability. Eds. Guy Burgess and Heidi Burgess. Conflict Research Consortium, University of Colorado, Boulder. Available at: <http://www.beyondintractability.org/essay/stereotypes/>.

Burgess Heidi (2003). "Damaged or Destroyed Relationships". Beyond Intractability. Eds. Guy Burgess and Heidi Burgess. Conflict Research Consortium, University of Colorado, Boulder. Available at: <http://www.beyondintractability.org/essay/damaged_relationships/>.

Carlsson Alf (1992). Cooperatives and the State: Partners in Development? A Human Resource Perspective. $\mathrm{PhD}$ Dissertation. Institute of International Education: Stockholm University.

Clark, Phil. (2010). The Gacaca Courts, post-Genocide Justice and Reconciliation in Rwanda: Justice without borders, New York: Cambridge University press. 
Dovidio John F., Peter Glick and Laurie A. Rudman (2005). "Introduction: Reflecting on the Nature of Prejudice: Fifty Years after Allport". In Dovidio, John F; Peter Glick, and Laurie A. Rudman. On the nature of prejudice: fifty years after Allport. Malden, MA; Oxford; Carlton, Victoria: Blackwell Publishing Ltd.

Dovidio John F., Samuel L. Gaertner and Kerry Kawakami (2003). "Intergroup Contact: The Past, Present, and the Future". Group Processes and Intergroup Relations: Sage publications, Vol. 6(1), pp.5-21.

Forbes H.D. (1997). Ethnic Conflict: Commerce, Culture and Contact Hypothesis. New Haven and London: Yale University Press.

Gibson Ryan (2005). The Role of Co-operatives in Community Economic Development. Working Paper, Rural Development Institute. Brandon University, Brandon: Manitoba.

Gilmartin Brian G. (1987). Shyness and Love: Causes, Consequences, and Treatment. University Press of America, Inc. Available at: http://www.love-

shy.com/Gilmartin/Chapter11/Principleofthesuper.html.

Hagengimana Athanase (2000, 2001). After Genocide in Rwanda: Social and Psychological Consequences. M.D. Harvard School of Public Health, Refugee Trauma Program/ University of Rwanda. Institute for the Study of Genocide, International Association of Genocide Scholars.

Hakelius Karin (1996). Cooperative Values-Farmers' Cooperatives in the Minds of the Farmers. Doctoral Dissertation. Swedish University of Agricultural Science: Uppsala.

Harris Ian M. (2004) Peace education theory, Journal of Peace Education, 1:1, $5-20$

Hoyt Ann (1996). And then there were Seven. Cooperative Principles Updated, Cooperative Grocer, Dave Gutknecht, Athens.

Hunger David and Louis W. Stern (1976). "An assessment of the Functionality of the Superordinate Goal in Reducing Conflict". The Academy of Management Journal, Vol. 19, No. 4, pp. 591-605.

International Cooperative Alliance (1995) "Statement on the Cooperative Identity". Review of International Cooperation, Report to the 31st Congress Manchester, 88.3.

International Institute of Social Studies (2013). Diversity, Inclusiveness and Social Cohesion, Working Paper, No 2013-1.

Kenworthy Jared B., Rhiannon N. Turner, Miles Hewstone and Alberto Voci (2005). "Intergroup Contact: When Does it Work, and Why?" (Chapter 17) In Dovidio, John F., Peter Glick, and Laurie A. Rudman (2005). On the Nature of Prejudice: Fifty years after Allport. Malden, Oxford, Carlton, Victoria: Blackwell Publishing, pp. 278-92.

Larsen, C.A., 2013. The Rise and Fall of Social Cohesion. The Construction and De-construction of Social Trust in the USA, UK, Sweden and Denmark. Oxford: Oxford University Press.

Lederach John Paul, Reina Neufeldt and Hal Culbertson (2007). Reflective 
Peacebuilding: A planning, monitoring, and Learning Toolkit. University of Notre Dame and catholic Relief Services. He Joan B. Kroc Institute for International Peace Studies.

Lederach John Paul (1997). Building Peace: Sustainable Reconciliation in Divided Societies. Washington, D.C.: United States Institute of Peace Press.

Love Mervyn T. (1995). Peacebuilding Through Reconciliation in Northern Ireland. Aldershot, Brookfield, Hong Kong, Singapore, Sydney: Avebury.

Miall Hugh (2004). “Global governance and conflict prevention”. In Feargal Cochrane, Rosaleen Duffy and Jan Selby (eds). Global governance, conflict and resistance, Basingstoke, United Kingdom: Palgrave, pp.5977.

Miller Daniel A., Eliot R. Smith and Diane M. Mackie (2004). "Effects of Intergroup Contact and Political Predispositions on Prejudice: Role of Intergroup Emotions". Group Processes Intergroup Relations. Vol. 7(3): Sage Publications, pp. 221-37.

MINALOC (2001). Dénombrement des Victimes du Génocide: Analyse des Résultats. Kigali.

NURC (2007). Annual Report, Kigali.

Ministry of Youth, Culture and Sports \& Ibuka Association (2004). Prevent and Banish Genocide forever, through universal active solidarity. International Conference on Genocide, Intercontinental Hotel, Kigali, $4^{\text {th }}-6^{\text {th }}$ April,

Pettigrew Thomas F. and Linda R. Tropp (2006). "A Meta-Analytic Test of Intergroup Contact Theory". Journal of Personality and Social Psychology, 2006, Vol. 90, No. 5, American Psychological Association, pp. 751-83.

Pettigrew Thomas F. (1998). "Intergroup contact theory". Annual Review of Psychology, Vol.49. Annual Review Inc., pp.65-85.

Ramsbotham Oliver, Tom Woodhouse, and Hugh Miall (2005). Contemporary Conflict Resolution. $2^{\text {nd }}$ Edition fully revised and expanded. Malden, Cambridge: Polity Press.

Ryan, Stephen (1995). "Peace-Building and Conflict Transformation". Chapter in Ethnic Conflict and International Relations. Dartmouth: Dartmouth Publishing, pp. 129-52.

Saunders Harold H (1999). A Public Peace Process. New York: Palgrave.

Schirch Lisa (2005). Ritual and Symbol in Peacebuilding. Bloomfield: Kumarian Press, Inc.

Schulz Michael (2008). "Reconciliation through education-experiences from the Israeli- Palestinian conflict". Journal of Peace Education.Vol.5, No1, pp.33-48.

Sentama, E. (2009). Peacebuilding in post-Genocide Rwanda: An exploration of the role of cooperatives in the restoration of interpersonal relationships, PhD Thesis, Gothenburg University, Göteborg, Sweden. 
Staub, E. (2003). The psychology of Good and Evil: Why children, Adults, and Groups Help and Harm others. Cambridge: Cambridge University Press.

Seitz Klaus (2004). Education and Conflict: The role of education in the creation, prevention and resolution of societal crises - Consequences for development cooperation. Eschborn: Deutsche Gesellschaft für Technische Zusammenarbeit (GTZ) GmbH, Available at: http://www.ineesite.org/uploads/documents/store/doc_1_48_EDandConflic t- GTZ.pdf)

Turner Rhiannon N., Richard J. Crisp and Emily Lambert (2007). "Imagining Intergroup Contact Can Improve Intergroup Attitudes". Group Processes and Intergroup Relations. Vol. 10(4): Sage Publications, pp. 427-41.

Worchel Stephen W., Frankie Y. Wong and Karen E. Scheltema (1989). "Improving Intergroup Relations: Comparative Effects of Anticipated Cooperation and Helping on Attraction for an Aid-Giver". Social Psychology Quarterly, Vol. 52, No. 3, American Sociological Association, pp. 213-19. 